\title{
SOME PRELIMINARY DATA ON THE NATURE/STRUCTURE OF THE PC-GLYCAN OF THE MAJOR EXCRETORY-SECRETORY PRODUCT OF ACANTHOCHELIONEMA VITEAE (ES-62)
}

\author{
HARNETT W*, FRAME M.J.*, NOR Z.M.*, MACDONALI) M.* ANI) HOLSTON K.M.*
}

\section{Summary :}

The structure of the PC-glycan of the major excretory-secretory product (ES-62) of Aconthocheilonema viteae has been investigated using endoglycosidases and lectins. Results obtained raise the possibility that it may be of the high mannose type. This, and the insensitivity of the PC-glycan to treatments which remove PC or choline from bacterial PC-glycans, suggests that it may be more analogous to fungal, than to bacterial PC-containing glycans.

KEY WORDS excretory-secretory product. phosphorylcholine. filariasis. glycan analysis.

MOTS-CLES : produif excrelant-secrelant phosphorylcholine, analyse des gly canes. filariose.

xcretory-secretory products (E-S) of filarial nematodes commonly contain phosphorylcholine (PC) (for a review, see Harnett and Parkhouse, 1994). The PC group is of some interest, as evidence is increasingly emerging that it may possess immunomodulatory activity. Within the last few years for example, it has been demonstrated that the $\mathrm{PC}$ moiety of filarial antigens is able to interfere with proliferative responses of both T- (Lal et al.. 1990) and B- (Harnett and Harnett, 1993) lymphocytes.

Work by Matizels and colleagues in 1987, suggested that the PC moieties associated with filarial nematode antigens were present on glycosylated molecules (Maizels et al., 1987), and more recently, the enzyme $\mathrm{N}$-glycosidase $\mathrm{F}$ has been employed to provicle evidence consistent with a covalent attachment of $\mathrm{PC}$ to glycan (Harnett et al, 1993). This latter form of structure is as far as we are aware, absent from humans. This, in association with the possible immunosuppressive capalility of $\mathrm{PC}$, suggests that the synthesis of $\mathrm{PC}$-glycans may represent a novel target for chemotherapeutic intervention. Towards this aim, we have initiated studies to elucidate the structure of the PC-glycans of filarial molecules. In this manuscript, we present some preliminary data on the structure of the PC-glycan of the major excretory-secretory product of Acanthocheilonema viteae (ES-62), (Harnett et al., 1989) and also consider its relationship to the PCglycan structures of bacteria and fungae.

The first strategy we adopted was designed to provide information on the type of $\mathrm{N}$-glycan, $\mathrm{PC}$ was attached to. This involved exposing ES-62 to endogly-

" Department of Immunology, University of Strathclycke. Glasgow G4 ONR, I'K.
Résumé : DONWÉS PRÉLIMTARES SIR LA NATL RE/STRLCTIRE. DF, LA PCGLYCANE DI PRINCIPAL PRODI'T' EXCRTANT-SECRÉTANT DH ACANITOCHHILONEHA ITTAL:

La siructure de la PC-glycane du principal produit excrétant-secrétant (ES-62) de Acanthocheilonema vitae a été étudié grâce a luvilisation d'endoglycosidases et de lectines. Les résultats obtenus développent la possibilité qu'elle pourrait être du type mannose. Cette hypothèse et linsensibilité de la PC-glycane aux traitements séparant la PC ou la choline des PC-glycanes bactériennes, suggèrent que cette structure serait plus proche des $P C$-glycanes fongiques que bactériennes.

cosiclases which are more specific in their action than $\mathrm{N}$-glycosidase $\mathrm{F}$. The endoglycosidases were purchased from Boehringer Mannheim Biochemica, and three were employed in the investigation : encloglycosidase D) (from I)iplococcus pneumoniae) which targets short chain "high mannose" glycans, encloglycosidase F (from Flavobacterium meningosepticum) which preferentially cleaves high mannose and hybrid types, and endoglycosidase $\mathrm{H}$ (from Streptomyces plicatus, from a recombinant $E . c o l i)$ which cleaves high mannose types. In addition, Nglycosidase $\mathrm{F}$ (from Flavobacterium meningosepticam was employed as a positive control.

$0.5 \mu \mathrm{g}$ samples of ES-62, purified as described previously (Harnett et al., 1993), were added to $10 \mu \mathrm{l}$ of $\mathrm{d}_{2} \mathrm{O}$. boiled for 3 mins, and then added to $30 \mu \mathrm{l}$ of the appropriate reaction buffer (see manufacturer of enzymes instructions). $10 \mu \mathrm{l}$ of $\mathrm{dH}_{2} \mathrm{O}$, containing $10 \mathrm{mg} / \mathrm{ml} \mathrm{BSA}$, and the following amounts of enzyme were then added : endoglycosidase $\mathrm{D}-0.1 \mathrm{mU}$; endoglycosidase $\mathrm{F}-5 \mathrm{mU}$; N-glycosidase $\mathrm{F}-20 \mathrm{mU}$; endoglycosidase $\mathrm{H}-0.1 \mathrm{mU}$. The samples were then incubated overnight at $37^{\circ} \mathrm{C}$. The amounts of endoglycosidases $\mathrm{D}, \mathrm{F}$, and $\mathrm{H}$ employed, were at least ten times greater than those considered necessary by the manufacturer. due to the known variation in susceptibility of glycoproteins to endoglycosidases (Beeley et al., 1985).

$10 \mu \mathrm{l}(100 \mathrm{ng})$ of endoglycosidase-treated ES-62 was subjected to Western blotting employing TEPC 15 (Sigma), an IgA mouse myeloma protein reactive for PC (Leon and Young, 1971), to detect PC epitopes and rabbit anti-ES-62 to detect $\mathrm{PC}$ and non-PC epitopes as described previously (Harnett et al., 1993). The result of this experiment demonstrated that only N-glycosi- 
dase $\mathrm{F}$ was able to remove $\mathrm{PC}$ from the molecule (not shown). More severe denaturation of the parasite product (boiling in the presence of SDS (0.1-1.0\%) and mercaptoethanol $(2 \%)$ prior to incubation with enctoglycosidases), did not alter the result. Each enzyme was tested for activity uncler the assay conditions to be employed prior to the analysis, and was shown to be active.

Our next strategy was to investigate the nature of the carbohydrate content of ES-62, by investigating its lectin binding characteristics. This was undertaken using a DIG (digoxigenin) glycan differentiation kit according to the manufacturer's instructions (Boehringer Mannheim Biochemica). $200 \mathrm{ng}$ aliquots of ES-62 were employed for dot blotting analysis. Hybond-C super nitrocellulose (Amersham) was employed as membrane.

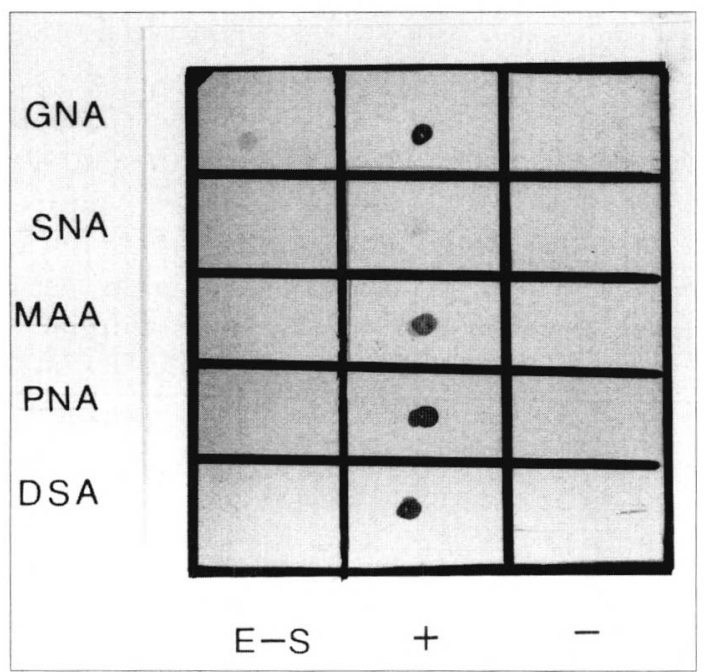

Figure 1. - Lectin analysis was undertatien using a DIG (digoxigenin) glycan differentiation kit according to the manufacturer's instructions (Bochringer Mannlueim Biochemica). $200 \mathrm{ng}$ aliquots of ES-62 (E-S and recommended amounts of positive $(+)$ and negarive $(-)$ control glycoproteins were employed in the dot lot analysis. Lectins employed were : (ialanthus niwallis algglutinin (GNA) - recognises terminal mannose linked to mannose (binds to high mannose or hybrid), Sambucus nigra agglutinin (SNA) - recognises sialic acid linked $\alpha(2-6)$ to galactose (binds to complex). Haackia ammrensis agglutinin (MAA) - recognises sialic acid linked $\alpha(2-3)$ to galactose (binds to complex). Peanut agglutinin (PNA) - recognises gallactose $\beta(1-3)$ N-acetylgalactosanine (O-glycans) and Dathra stramonium igghlutinin (DSA) - recognises Gall-(1-4)G1CNAC (binds to complex and hybrid)

All lectins were found to bind to their appropriate positive controls, but only GNA was found to bind to the parasite product (Fig. 1). This demonstrates the presence of terminal mannose, $\alpha(1-3), \alpha(1-6)$, or $\alpha(1-$ 2) bound to mannose, and is indicative of a "high mannose" or "hybrid" N-glycan chain. Such a structure was also indicated when it was demonstrated that Con A also specifically bound to ES-62 (result not shown). Lectins which bind other glycan structures found in complex or hybrid $\mathrm{N}$-glycans failed to inter- act with ES-62 (Fig. 1). The latter finding is consistent with the terminal mannose sugars being detected, residing on a high mannose, rather than hybrid glycan. The results failed to show any evidence of $\mathrm{O}$ glycans, an olsservation consistent with the finding that $\mathrm{N}$-glycosidase F removes all glycans from ES-62 (Houston and Harnett, unpublished).

The lectin binding analysis indicates that ES-62 contains a high mannose or hybrid glycan (probably the former) but it is not known as to whether this is the glycan which contains PC. (Prolonged pronase digestion of ES-62 followed by column chromatography suggests there may be two glycans present - Bonay P. and Harnett $W$., unpublished). High mannose glycans would be expected to be cleaved by endoglycosidases $F$ and $H$, and hybrid glycans, by endoglycosidase $F$ Since these enzymes do not promote removal of $\mathrm{PC}$ from ES-62, it can be argued that the glycan being detected lacks PC. However, Western blotting analysis of ES-62 subjected to endoglycosidases, demonstrates no obvious shift in molecular weight of the parasite product, a result consistent with a failure to remove any glycan. Thus the lack of cleavage may be due to either the appropriate target bond not being exposed to the enzymes, or alternatively to "something" preventing cleavage. If the latter is correct, then clearly the PC could be the "something" in question.

In an attempt to address this question we subjected ES-62 to several strategies designed to remove PC. It has previously been shown that PC is attached to carbohydrate in the cell wall of certain bacteria (Tomasz, 1967), and that this can be cleaved using phospholipase C(PLC) (Beckmann and Levitt, 1984). We therefore exposed ES-62 (including denatured) to PLC using the protocol of the authors, but found by Western blotting that there was no removal of $\mathrm{PC}$ (result not shown). The PLC was tested for activity prior to use (Krug et al. 1979), and shown to be active.

Choline in bacterial cell walls is linked to sugars via phosphodiester bonds (Bennett and Bishop, 1977), and hence the idea was considered that a similar arrangement may operate with respect to filarial E-S products. Phosphodiester bonds in lysosomal enzymes can be broken by boiling at $100^{\circ} \mathrm{C}$ for 30 mins in $0.01 \mathrm{~N} \mathrm{HCl}$ (Gabel et al., 1982); phosphodiester bonds in yeast mannan can be broken by boiling at $100^{\circ} \mathrm{C}$ in $0.1 \mathrm{~N} \mathrm{HCl}$ (Thieme and Ballou, 1971). Choline phosphate is normally stable to acid, but may break with phosphodiester linkage. ES-62 was therefore subjected to boiling in $0.1 \mathrm{~N} \mathrm{HCl}$ for four hours. This however was found by Western blotting to fail to release the PC (result not shown). It was also noted that boiling ES-62 in $0.01 \mathrm{~N} \mathrm{NaOH}$, a treatment shown to remove choline from $\mathrm{PC}$ in Pneumococcus (Bennet and Bishop, 1977) had virtually no effect in 
removing PC from ES-62 as shown by Western blotting (result not shown).

Finally, worms were cultured in choline-free medium for a period of 14 days and ES-62 purified from the spent culture medium as described previously, but on a daily basis (Harnett et al., in press). At the end of this period however, it was observed using Western blotting, that the worms were still producing $\mathrm{PC}$. Clearly therefore either the worms have long lasting stores of choline. or alternatively, they possess the biochemical machinery to synthesise it.

With all four approaches therefore, we were unsuccessful in attempting to produce PC-free ES-62. The failure of phospholipase $\mathrm{C}$ and alkalki to remove $\mathrm{PC}$ or choline from ES-62 is of some interest as it suggests the structure we are dealing with is rather different from that found in bacteria. The bacterial PC glycans are part of the cell wall C-polysaccharide and have $\mathrm{PC}$ attached to sugars such as rhamnose (Bennet and Bishop, 1977) or $\mathrm{N}$-acetylgalactosamine (Beckmann and Levitt, 1984). The indications from the present study suggest that PC may be attached to mannose and hence the PC sugar interaction of ES-62 may perhaps be more analogous to that found in the 5-O-B-D-galactofuranosyl-containing peptidophosphogalactomannan of Penicillium charlesii (Unkefer and Gander, 1990). This mannan is attached through an O-glycosiclic linkage, but contains approximately 10 phosphoethanolamine and phosphocholine residues attached as phosphodiesters to mannosyl C-6 residues. No information was presented on the susceptibility of the phosphodiester bonds to acid and alkali treatments such as those employed in the present study. It is also worth noting that PC-containing peptidopolysaccharides of a number of fungal species, but not the bacterium Diplococcus pneumoniae, interact with Con A (Baldo et al., 1977), and that this is a possible property of the PC-glycan of ES-62.

In summary. preliminary experiments suggest that the N-linked glycan of ES-62 which contains PC, may be of the high mannose type. This, and the insensitivity of the PC-glycan to treatments which cleave bacterial PC-glycans, raises the possibility that the PC-glycan of ES-62 may be more analogous to fungal, than to bacterial PC-containing glycans. Sophisticated characterisation methodologies are currently being employed to further investigate these possibilities.

\section{REFERENCES}

Baldo B.A., Fiftcher T.C. and Pepys J. : Isolation of a peptido-polysaccharide from the dermatophyte Epidermophyton floccosum and a study of its reaction with human C-reactive protein and a mouse anti-phosphorylcholine myeloma serum. Immunology, 1977, 32, 831-842.
Beckimann E. and LevitT I). : Phosphorylcholine on Streptococcus pneumoniae $\mathrm{R} 36 \mathrm{a}$ is responsible for in titro polyclonal antibody secretion by human peripheral blood lymphocytes. Journal of Immunology, 1984, 132, 21742176.

BEFLEY J.G. : Laboratory Techniques in Biochemistry and Molecular Biology, vol. 16. Glycoprotein and Proteoglycan Techniques, Elsevier, Amsterdam, 1985.

BENNET L.G. and Bishop C.T. : Structure of the type XXVII Streptococcus pneamoniae (pneumococcal) capsular polysaccharide. Canadian Joumal of Chemistrn: 1977, 55. 8-16.

Gabi: C.A., Golinerg D.E. and Kornfield) S. : Lysosomal enzyme oligosaccharide phosphorylation in mouse lymphoma cells : specificity and kinetics of binding to the mannose 6-phosphate receptor in tivo. foumal of Cell Biology: 1982, 95, 536-543.

Harnet"l W., Hotston K.M., Amess R, and Worms M.J. : Acanthocbeilonema viteae: phosphorylcholine is attached to the major excretory-secretory product via an N-linked glycan. Experimental Parasitology, 77. 498-502.

HaRNitT W. and HarnitT M.M. : Inhibition of murine $B$ cell proliferation and downregulation of protein kinase $C$ levels by a phosphorylcholine-containing filarial excretory-secretory product. Joumal of Immunology: 1993. 151, 4829-4837.

HARNETT W. and PARKHOLSE R.M.E. : The nature and function of nematode surface and excretory-secretory antigens. In: Perspectives in nematode physiology and biochemistry. Sood M.L. (ed.) M S Naredra Publication House, New Delhi, 1994, in press

Harnet' W., Worms M.J., Kapil. A., Grainger M. and Parkiolse R.M.E. : Origin, kinetics of circulation and fate in 'il'o of the major excretory-secretory product of Acanthocheilonema titecie. Parasitology, 1989, 99, 229239).

Krig L., Truestoale N.J. and Kent C. : A simplified assay for phospholipase C. Analytical Biochemistry: 1979. 97. 4347.

Lai. R. B., Kimaraswami V., Stemi. C. and Netman T. B. : Phosphocholine-containing antigens of Brugia malayi non specifically suppress lymphocyte function. American Joumal of Tropical Hedicine and Hygiene, 1990, 42, 5664.

LEON M.A. and Young N.M. : Specificity for phosphorylcholine of six murine myeloma proteins reactive with Pneumococcus C polysaccharide and B-lipoprotein. Biochemistry, 1971, 10, 1424-1429.

MaIzELS R.M., BURKE J. and DENHAM D.A. Phosphorylcholine-bearing antigens in filarial nematode parasites : analysis of somatic extracts, in vitro secretions and infection sera from Brigia malay $i$ and B. pabangi. Parasite Immunologl', 1987, 9, 49-66.

Thime T.R. and Balior C.F. : Nature of the phosphodiester linkage of the phosphomannan from the yeast Kloeckera bretis. Biochemistry: 1971, 10, 4121-4128.

Tovasz T. : Choline in the cell wall of a bacterium : novel type of polymer-linked choline in Pnemmococcus. Science, 1967, 157, 694-697.

LNKFFER C.J. and GANDER JE. : The 5-O-B-I) gallactofuranosyl-containing peptidophosphogalactomannan of Penicillium charlesii. Joumal of Biological Chemistry. $1990,265,685-689$. 